\title{
REVIEWS
}

Piel. Zdr. Publ. 2015, 5, 4, 393-399

(c) Copyright by Wroclaw Medical University

DOI: $10.17219 / \mathrm{pzp} / 60172$

ISSN 2082-9876

\author{
Katarzyna Neubauer ${ }^{1, D-F}$, Iga Gromny ${ }^{2, D-F}$
}

\section{Colorectal Cancer: Does Diet Matter?}

\section{Rak jelita grubego. Czy dieta ma znaczenie?}

\author{
${ }^{1}$ Klinika Gastroenterologii i Hepatologii, Katedra Gastroenterologii i Hepatologii, Uniwersytet Medyczny \\ im. Piastów Śląskich we Wrocławiu, Wrocław \\ ${ }^{2}$ Zakład Dietetyki, Katedra Gastroenterologii i Hepatologii, Uniwersytet Medyczny im. Piastów Śląskich \\ we Wrocławiu, Wrocław
}

A - research concept and design; $\mathbf{B}$ - collection and/or assembly of data; C - data analysis and interpretation;

$\mathbf{D}$ - writing the article; $\mathbf{E}$ - critical revision of the article; $\mathbf{F}$ - final approval of article

\begin{abstract}
Colorectal cancer (CRC) is the most common malignancy of the gastrointestinal tract and one of the most common malignancies among men and women in Western countries. The role of dietary factors in CRC development seems to be significant, however, showing the relation of dietary factors in CRC remains challenging. Data supporting the interaction between diet and malignancy development come from: studies with an animal model of the disease, observations regarding geographical variation in CRC incidence, and different studies in people, especially long-term prospective investigations. The most important factor seems to be fiber. Additionally, recently published studies have shown that the diet-related disease obesity is also a risk factor of CRC. Adipokines, substances produced and secreted by adipose tissue, are proposed as a link between obesity and carcinogenesis. Genetic studies will possibly elucidate the complex interactions lying in the background of the development of the malignancy. Moreover, the gut microbiome seems to also play a role. Our paper discusses the current knowledge regarding CRC and diet (Piel. Zdr. Publ. 2015, 5, 4, 393-399).
\end{abstract}

Key words: colorectal cancer, fiber, obesity, diet.

\section{Streszczenie}

Rak jelita grubego jest najczęstszym nowotworem złośliwym przewodu pokarmowego i jednym z najczęściej występujących nowotworów złośliwych wśród kobiet i mężczyzn w krajach zachodnich. Znaczenie czynników dietetycznych w rozwoju raka jelita grubego wydaje się ważne, ale udowodnienie związku przyczynowego czynnik dietetyczny-rak pozostaje wyzwaniem. Za znaczeniem czynników dietetycznych przemawiają: zróżnicowanie geograficzne w częstości występowania nowotworów, badania na modelu zwierzęcym choroby, różnego typu badania prowadzone u ludzi, z których za najważniejsze można uznać trwające wiele lat badania prospektywne. Najważniejszym czynnikiem wydaje się błonnik. Poza tym, ostatnio opublikowane badania wykazały, że otyłość, choroba związana z dietą, jest również czynnikiem ryzyka raka jelita grubego. Wśród substancji, które mogą stanowić ogniwo łączące otyłość i raka jelita grubego są wymieniane adipokiny produkowane i wydzielane przez trzewną tkankę tłuszczową. Złożone związki leżące u podłoża rozwoju raka prawdopodobnie zostaną wyjaśnione również dzięki badaniom genetycznym. Podnosi się także rolę mikroflory jelita grubego. Artykuł omawia aktualne poglądy na temat związku między dietą a rakiem jelita grubego (Piel. Zdr. Publ. 2015, 5, 4, 393-399).

Słowa kluczowe: rak jelita grubego, błonnik, otyłość, dieta.

Colorectal cancer (CRC) is the most common malignancy of the gastrointestinal tract. CRC is the third most common cancer worldwide, with 1.2 million cases and 608,000 deaths in 2008 and with most of the cases occurring in developed countries. CRC is more prevalent in Europe, North
America, Argentina, Australia, New Zealand, and Japan, and this is the reason it is commonly known as a Western lifestyle disease [1]. Moreover, there is an increase in the incidence of CRC in countries adopting a Western lifestyle. These observations deliver an argument for the significance of an 
environmental factor in CRC development. Diet, which typically for Western countries is usually rich in processed food and fat and poor in fiber, is connected to a higher risk of CRC. On the other hand, some patterns of diet like Nordic or Mediterranean may deflect the risk of CRC, because of the high amount of healthy ingredients such as fiber or vitamin D. Some dietary factors (i.e. fiber, fish and red and processed meat) may play a major role in CRC etiology. The interaction between those dietary factors, genes and biochemical mechanisms determine the carcinogenesis. However, the mechanism of the effect of dietary factors is complex, not fully elucidated and debatable.

\section{Dietary Factors}

\section{Fruits, Vegetables and Fiber}

A diet rich in fiber, which is an indigestible element of food derived from plants, vegetables and fruits, is associated with a reduction of CRC risk.

For instance, the European Prospective Investigation into Cancer and Nutrition (EPIC), a cohort study conducted in 23 centers from 10 European countries, after an analysis of 1025 cases of CRC, showed that high fiber intake had a great protective effect in the left colon and the least in the rectum. No food source of fiber was proved to be significantly more protective than others. The authors concluded that the results achieved make it possible to predict a $40 \%$ reduction in CRC risk following doubled intakes of fiber [2]. Terry et al. studied fruit, vegetable and fiber consumption and the risk of CRC among a Swedish female population known for a low intake of fruit and vegetables and their high consumption of cereals. They found a 32\% reduction in the risk of $\mathrm{CRC}$ in individuals with a high consumption of fruit and vegetables and a high consumption of cereal fiber did not decrease the risk of CRC [3].

Levi et al. documented a significant inverse association between total fiber intake and risk of CRC and between certain types of fiber and CRC among 286 patients with CRC ( 149 with colon cancer, 137 with rectal cancer and 550 controls). The researchers suggested that vegetable fiber may be more protective than other fruit or grain fiber [4].

The Netherlands Cohort Study on Diet and Cancer did research on the association between fruit and vegetable consumption and the risk of CRC. As far as colon cancer is concerned, no statistically significant associations with total vegetable intake or total fruit intake were confirmed. Even so, among women, an inverse association was observed with vegetables and fruit. Brassica vegetables and cooked leafy vegetables showed an in- verse relation for both men and women. Among women and, to a lesser extent among men, the inverse associations were stronger for distal colonic tumors than for proximal colonic tumors. For rectal cancer, no statistically significant associations were found for vegetable consumption or fruit consumption or for specific groups of vegetables and fruits; only Brassica vegetables showed a positive association in women. As in other cohort studies, the observed inverse relation between vegetable and fruit consumption and the occurrence of colorectal cancer was less strong than relations reported in case-control studies [5].

\section{Mechanisms of Action}

Two kinds of fiber have been distinguished: soluble and insoluble. Bran fiber is insoluble; fruit and vegetable fiber seems to be more soluble. Insoluble fiber has a bulking proprietes while soluble fiber is fermented by colonic bacteria to short chain fatty acids like butyrate (BT) which has anti-infmmatory proprieties.

BT plays a main role in homeostatic functions including the ability to prevent or even inhibit carcinogenesis. BT is transported into colonic epithelial cells by two types of transport systems: monocarboxylate transporter 1 (MCT 1) and sodium-coupled monocarboxylate transporter 1 (SMCT1). Under normal conditions, BT is the main source of energy for normal colon cells. Colonic epithelial tumor cells show a reduction in BT uptake (reduction in MCT 1 and SMCT 1 protein expression), glucose uptake and glycolysis become their fundamental energy source. BT has an anticarcinogenic effect (induction of cell differentiation, apoptosis and inhibition of cell proliferation) while it has the opposite effect on the growth of normal colonocytes. This phenomenon is called "the BT paradox" [6].

It is documented that cruciferous vegetables have a chemopreventive effect because of their high content of glucosinolate metabolites, which are thought to cause apoptosis, inhibit cell proliferation and reduce pro-inflammatory reactions. The repress NFkB, GSTM1, GSTT1 and GSTP1 which encode the glucosinolates metabolizing enzyme glutathione S-transferases.

Some researchers have suggested that a high consumption of fat and meat and a low intake of fiber increases the genotoxicity of fecal water to colonic cells, and this may contribute to a rise of CRC risk [7]. Additionally, some researchers have indicated that suberin and lignin, which are plant cell-wall constituents, absorb HCA, which is an carcinogenic agent [8]. For example, potato skins contain suberin while wheat bran contains lignin. 


\section{Meat}

High consumption of red meat may lead to an increasing risk of CRC from $28 \%$ to $35 \%$ and higher intake of processed meat may be responsible for a rise in risk from $20 \%$ to $49 \%$ [9]. The World Cancer Research Fund has concluded that there is strong evidence that red and processed meat poses a significant risk of CRC. The Cancer Prevention Study II Nutrition Cohort suggests that greater red and processed meat intake before diagnosis is associated with higher mortality among patients with non-metastatic CRC. This study was conducted among 2315 participants with CRC. Nine hundred sixty six died during the follow-up period (413 from CRC).

Another interesting study was a case-control study conducted in Pennsylvania. It included 1005 incident cases and 1062 controls. This study documented the role of dietary iron, heme iron and supplemental iron on CRC risk. The research showed that dietary iron intake was inversely associated with CRC among women but not among men. Intake of more than $18 \mathrm{mg}$ a day of supplemental iron was positively associated with CRC incidence both among women and men. This suggests that intake of more than $18 \mathrm{mg}$ /day of supplemental iron may increase the risk of CRC [10].

What is more, some studies show that the risk of CRC cancer depends on the type of red meat which is consumed. A study was conducted among 53,988 participants; 644 cases of colon cancer and 345 cases of rectal cancer. No associations were found between the intake of red meat, processed meat, fish, or poultry and risk of CRC. Risk was associated with the subtype of red meat depending on the animal of origin. There was an association between higher intake of lamb and higher risk of CRC. Additionally, the risk of CRC was elevated during higher intake of pork [11].

Sihna et al. also found evidence of increased CRC adenoma risk with consumption of certain types of red meat. The increased risk was mainly associated with well-done/very well-done red meat, with an excess risk of $29 \%$ per $10 \mathrm{~g} /$ day (OR, 1.29; CI, $1.08-1.54)$ vs. an excess of $10 \%$ per $10 \mathrm{~g} /$ day (OR, 1.10; CI, 0.96-1.26) for consumption of rare/medium red meat. High-temperature cooking methods were also associated with increased risk; $26 \%$ per $10 \mathrm{~g} /$ day (OR, 1.26; CI, 1.06-1.50) of grilled red meat and $15 \%$ per $10 \mathrm{~g} /$ day (OR, 1.15 ; CI, 0.97-1.36) of pan-fried red meat consumption [12].

A high risk of CRC may be caused directly by high consumption of meat or indirectly because a diet high in meat tends to be low in fruit, vegetables and fiber.
A case control study was conducted by Bidoli et al. in the Pordenone province of north-eastern Italy, on 123 cases of colon cancer, 125 cases of rectal cancer and 699 controls. This study showed that a high consumption of refined starches, eggs, cheese and red meat contribute to a higher risk of CRC while a fiber-rich or vegetable-rich diet is a protection from CRC [13].

\section{Mechanism of Action}

Processed meat involves nitric compounds. These alkaline agents may react with DNA, causing carcinogenesis. Nitric compounds like nitrosamines need metabolic activation to be converted into a carcinogenic agent. Similarly, heterocyclic amines (HCA) can lead to carcinogenesis by causing mutations in DNA [9]. Red and processed meat contain carcinogenic HCA, polycyclic aromatic hydrocarbons (PAH) and N-Nitroso compounds produced by cooking at high temperature and during meat processing. $\mathrm{N}$-acetyltransferases coded by NAT1 and NAT2 are enzymes which activate HCA and PAH.

\section{Fish}

Some studies show a strong association between higher intake of fish and lower risk of colon cancer but not rectal cancer.

For instance, a study by Jędrychowski et al. suggests that fish consumption decreases the risk of CRC. This hospital case-control study was performed among 548 CRC patients (of the Surgery Clinic, University Hospital in Kraków, Poland). The control group consisted of 745 patients of the same hospital with no history of cancer admitted for treatment of non-neoplastic conditions. Additionally, the study showed that intake of stewed or cooked meat increased the risk of CRC. This is further evidence that processed meat may contribute to a higher risk of CRC [14].

Another example study is the Fukuoka Colorectal Cancer Study, covering 782 cases and 793 controls. This study presents no association between beef, pork, processed meat, total fat or 6-PUFA (polyunsaturated fatty acid) consumption and increased risk of CRC, but on the other hand, it indicates that higher fish intake has an influence on the elimination of high CRC risk [15].

\section{Mechanism of Action}

Eicosapentaenoic acid (EPA) and docosahexaenoic acid (DHA) are naturally occurring omega $(\omega)$-3 long-chain polyunsaturated fatty acids, which are found in their highest quantities in oily fish such as sardines and mackerel [16]. 
Fish consumption is associated with a reduction in the risk of CRC because of PUFA, which reduces inflammation-driven carcinogenesis in the colon. It causes down-regulation of PGE2 and cyclo-oxygenase-2 (COX2) (arachidonic acid pathway). PUFA has the ability to modulate the variety of genomic and immune responses. It decreases the C-reactive protein/albumin ratio.

\section{Dairy Products}

Studies shows that milk and cheese play an important role in reducing CRC risk. Dietary calcium and calcium dairy products are also significantly inversely associated. This reducing of CRC risk effect may be attributed to the fact that dairy products like milk and cheese consist of a lot of calcium. In general, cohort studies have found that milk and dairy products have a protective effect on CRC, but case-control studies do not support this relationship [17].

The European Prospective Investigation into Cancer and Nutrition (EPIC) investigated the associations between intakes of total milk and milk subtypes (whole-fat, semi-skimmed and skimmed), yogurt, cheese, and dietary calcium and colorectal cancer risk amongst 477,122 men and women. The results of this study suggest that dairy products may play a protective role from developing CRC [18].

Aune et al. conducted a systematic review to clarify the character of the association between dairy product consumption and the risk of CRC. This meta-analysis indicates that milk and total dairy products, but not cheese and other dairy products, reduce the risk of CRC [19].

\section{Mechanism of Action}

The most essential components of dairy products which may be responsible for the reduction the CRC risk are calcium and vitamin D. This protective effect seems to be the result of 2 types of mechanisms: reducing proliferation and inducing differentiation of cells. The effects of vitamin $\mathrm{D}$ and calcium may be mediated by the vitamin $\mathrm{D}$ receptor (VDR), which is encoded by the VDR gene [20].

\section{Nuts}

The EPIC study documented that higher nut and seed intake is not significantly associated with the risk of CRC in men but did show an inverse association with CRC in women.

\section{Alcohol}

The data confirms that current alcohol intake is positively associated with the risk of rectal but not of colon cancer [21]. What is more, excessive alcohol consumption has been associated with elevated risk of CRC. Meanwhile, the effect of medium alcohol intake on CRC risk is unclear [22]. Drinking $>1$ drink/day increases the risk of CRC [23].

\section{Mechanism of Action}

Ethanol itself is not carcinogenic but the available data suggests that acetaldehyde (AA) and reactive oxygen species, both products of ethanol metabolism, have a genotoxic effect, promoting carcinogenesis. Other carcinogenetic mechanisms include nutritional deficits, changes in DNA methylation, and impaired immune surveillance. Alcohol has a direct mucosal effect and indirect effects mediated by the mechanical pressure determined by gas. The role of sugar or artificial sweeteners is also debated as factors involved in the carcinogenic processes [24]. What is interesting is, there is a correlation between alcohol drinking and smoking. Tobacco may be responsible for mutations in DNA. It is harder to repair it while alcohol is present. Moreover, smoking changes the oral bacterial flora, increasing acetaldehyde. On the other hand, alcohol can be treated as a solvent which simplifies the penetration of other carcinogenic substances. High amounts of alcohol contribute to decreasing valuable nutrients - the tissues are more susceptible to carcinogenesis [25].

\section{Mediterranean Diet}

The basic components of the Mediterranean diet are: fruits, vegetables, fish, whole grains, dairy products and small amounts of red and processed meat and sweets. Some studies have documented that this type of diet decreases the risk of CRC [26, 27].

The EPIC study found an association between keeping a Mediterranean diet and the risk of CRC. The results show that the Mediterranean diet may reduce the risk of CRC from 3 to $4 \%$. These connections were more noticeable among women. This study suggests that a Mediterranean diet may have a positive influence on the risk of CRC.

\section{Nordic Diet}

The Nordic diet is based on products like boiled potatoes, whole-grain wheat and rye bread, oats, barley, fermented milk and red meat. A sum- 
Table 1. Dietary factors and CRC

Tabela 1. Czynniki żywieniowe i CRC

\begin{tabular}{|c|c|c|}
\hline $\begin{array}{l}\text { Diet factors which change the } \\
\text { risk of CRC }\end{array}$ & CRC risk & Major components of action \\
\hline Fiber, fruit, vegetables & $\downarrow$ & $\begin{array}{l}\text { butyrate: anti-inflammatory proprieties } \\
\text { Suberin, lignin: absorbing carcinogenic agents }\end{array}$ \\
\hline Nuts & $\downarrow / \uparrow$ & \\
\hline Fish & $\downarrow$ & $\begin{array}{l}\text { PUFA: reducing inflammation-driven carcinogenesis in the colon, } \\
\text { down-regulation of PGE2 and cyclo-oxygenase-2 (COX2) (arachidonic } \\
\text { acid pathway). Modulating the variety of genomic and immune re- } \\
\text { sponses, decreasing C-reactive protein/albumin ratio }\end{array}$ \\
\hline Red and processed meat & $\uparrow$ & nitric compounds: reaction with DNA-carcinogenesis, HCA, PAH \\
\hline Dairy products & $\downarrow$ & $\begin{array}{l}\text { calcium, vitamin D: reducing proliferation and inducing differentia- } \\
\text { tion of cells }\end{array}$ \\
\hline Alcohol & $\uparrow$ & $\begin{array}{l}\text { acetaldehyde: genotoxic effect promoting carcinogenesis, binding to } \\
\text { DNA and proteins, destructing folate, hyperproliferations } \\
\text { reactive oxygen: genotoxic effect promoting carcinogenesis }\end{array}$ \\
\hline
\end{tabular}

$\uparrow$ - increase the risk of CRC; $\downarrow$ - decrease the risk of CRC; $\downarrow / \uparrow ~-~ u n c l e a r ~ e f f e c t$.

mary review shows that whole grains, which are an important component of Nordic diet, may be a protection against CRC [28].

\section{Obesity and CRC}

It is estimated that about $20 \%$ of all cancers are caused by obesity [29]. What is more, around $11 \%$ of colorectal cancer (CRC) cases have been associated with overweight and obesity in Europe. Obesity increases the risk of CRC from 30\% to $70 \%$ in men, whereas this association is less significant in women [30]. Obesity, which is a diet-related disease, is a well-known risk factor of CRC [31]. Adipokines, substances produced and secreted by adipose tissue, possessing proinflammatory properties, are proposed as a link between obesity and carcinogenesis.

For instance, reports from the International Agency for Research into Cancer and the World Cancer Research Fund (WCRF) indicate that there is a strong association between obesity and a high risk of CRC. Several factors may be relatively strongly associated with higher CRC risk: insulin, insulin-like growth factor-1, sex steroids, and adipokines [32].

Moreover, Perrigue et al. suggest that high eating frequency may have an influence on CRC risk. They found an inverse association between eating frequency and CRC [33].

A meta-analysis by Ben et al. indicates that increased BMI is associated with a higher risk of colon but not rectal adenoma [34]. Another meta-analysis also found a relationship between high $\mathrm{BMI}$ and an increased risk of CRC [35].

\section{Intestinal Microflora and CRC}

The human gastrointestinal tract contains more than $10^{12}$ microorganisms in one gram of the stool. There are about 1000 species of microorganisms which colonize the large and small intestine.

The gut microflora is a complex of different microorganisms which creates a special kind of ecosystem. Its activity has a great influence on human health [36]. Some types of commensal bacteria, for example E. coli, Bacteroides fragilis and Streptococcus bovis, are connected with an elevated risk of CRC. As an example, Bacteroides fragilis may cause carcinogenesis by a hyperproliferation of cells and proinflammatory proprieties. What is more, it may increase the genotoxicity of HCA, a carcinogenic agent produced during high temperature cooking of meat. On the other hand, other types of bacteria like bifidobacteria may play a protective role [37]. It has been observed that the amount of bifidobacteria in the mucosa-adherent microbiota is reduced among patients with CRC [38].

\section{Summary}

The role of dietary factors that could contribute to high CRC incidence still remains unclear. In the contemporary world, people have more choices of the variety of food thanks to the omnipresent advanced technology. Different patterns of diet contain a variety of dietary factors, sometimes both healthy and unhealthy. Because of the combination of nutrients and foods, we cannot in- 
vestigate a single diet factor which causes CRC. Therefore, studies show that some specific dietary patterns may be associated with a higher risk of CRC. Studies have presented that the Western dietary pattern, like eating processed red meat, fatty food, alcohol, etc., significantly increases CRC incidence. Dairy food, for example milk, fish, vegetables and fruit are factors which may also affect the risk of CRC. A major step toward reducing the risk of CRC is elimination of the carcinogen, or at least minimizing exposure, but without a full identification of the corresponding risk factors, it is difficult to put into practice these actions in primary prevention. It is estimated that more than two-thirds of cancer cases could be prevented through appropriate lifestyle modifications [39].

\section{References}

[1] Ferlay J., Shin H.R., Bray F., Forman D., Mathers C., Parkin D.M.: Estimates of worldwide burden of cancer in 2008: GLOBOCAN 2008. Int. J. Cancer. 2010, 127, 2893-2917.

[2] Bingham S.A., Day N.E., Luben R., Ferrari P., Silmani N., Norat T., Clavel-Chapelon F., Kesse E., Nieters A., Boeing H., Tjonneland A., Overad K., Martinez C., Dorronsoro M., Gonzales C.A., Key T.J., Trichopolou A., Naska A., Vineis P., Tumino R., Krogh V., Buendo-de-Mesquita H.B., Peeters P.H., Berglund G., Hallmans G., Lund E., Skeie G., Kaaks R., Riboli E.: Dietary fibre in food and protection against colorectal cancer in the European Prospective Investigation into Cancer and Nutrition (EPIC): an observational study. Lancet 2003, 361, $1496-1501$.

[3] Terry P., Giovannuci W., Michels K.B., Bergkvist L., Hansen H., Wolls A.: Fruit, vegetables, dietary fiber, and risk of colorectal cancer. JNCI 2001, 93, 525-533.

[4] Levi F., Pasche C., Lucchini F., La Vecchia C.: Dietary fibre and the risk of colorectal cancer. Eur. J. Cancer 2001, 37, 2091-2096.

[5] Voorrips L.E., Goldbohm R.A., Van Poppel G., Sturmans F., Hermus R.J., Van den Brandt P.A.: Vegetable and fruit consumption and risks of colon and rectal cancer in a prospective cohort study: The Netherlands Cohort Study on Diet and Cancer. Am. J. Epidemiol. 2000, 152, 1081-1092.

[6] Goncalves P., Martel F.: Butyrate and colorectal cancer: the role of butyrate transport. Curr. Drug Metab. 2013, 14, 994-1008.

[7] Rieger M.A., Parlesak A., Pool-Zobel B.L., Rechkemmer G., Bode C.: A diet high in fat and meat but low in dietary fibre increases the genotoxic potential of "faecal water". Carcinogenesis. 1999, 20, 2311-2316.

[8] Ryan-Harshman M.: Diet and colorectal cancer. Review of the evidence. Can. Fam. Phys. 2007, 53, 1913-1920.

[9] Zandonai A.P., Sonobe H.M., Sawada N.O.: The dietary risk factors for colorectal cancer related to meat consumption. Rev. Esc. Enferm. USP. 2012, 46, 234-239.

[10] Ashmore J.H., Lesko S.M., Miller P.E., Cross A.J., Muscat J.E., Zhu J., Liao J., Harper G., Lazarus P., Hartman T.J.: Association of dietary and supplemental iron and colorectal cancer in a population-based study. Eur. J. Cancer Prev. 2013, 22, 506-511.

[11] Egeberg R., Olsen A., Christensen J., Halkjær J., Jakobsen M.U., Overvad K., Tjønneland A.: Associations between red meat and risks for colon and rectal cancer depend on the type of red meat consumed. J. Nutr. 2013, 143, 464-472.

[12] Sinha R., Chow W.H., Kulldorff M., Denobile J., Garcia-Closas M., Weil R., Hoover R.N., Rothman N.: Well-done, grilled red meat increases the risk of colorectal adenomas. Cancer Res. 1999, 59, 4320.

[13] Bidoli E., Franceschi S., Talamini R., Barra S., La Vecchia C.: Food consumption and cancer of the colon and rectum in north-eastern Italy. Int. J. Cancer. 1992, 50, 223-229.

[14] Jedrychowski W., Maugeri U., Pac A., Sochacka-Tatara E., Galas A.: Protective effect of fish consumption on colorectal cancer risk. Hospital-based case-control study in Eastern Europe. Ann. Nutr. Metab. 2008, 53, $295-302$.

[15] Kimura Y., Kono S., Toyomura K., Nagano J., Mizoue T., Moore M.A., Mibu R., Tanaka M., Kakeji Y., Maehara Y., Okamura T., Ikejiri K., Futami K., Yasunami Y., Maekawa T., Takenaka K., Ichimiya H., Imaizumi N.: Meat, fish and fat intake in relation to subsite-specific risk of colorectal cancer: The Fukuoka Colorectal Cancer Study. Cancer Sci. 2007, 98, 590-597.

[16] Hull M.A.: Omega-3 polyunsaturated fatty acids. Best Pract. Res. Clin. Gastroenterol. 2011, 25, 547-554.

[17] Norat T., Riboli E.: Dairy products and colorectal cancer. A review of possible mechanisms and epidemiological evidence. Eur. J. Clin. Nutr. 2003, 57, 1-17.

[18] Murphy N., Norat T., Ferrari P., Jenab M., Bueno-de-Mesquita B., Skeie G., Olsen A., Tjønneland A., Dahm C.C., Overvad K., Boutron-Ruault M.C., Clavel-Chapelon F., Nailler L., Kaaks R., Teucher B., Boeing H., Bergmann M.M., Trichopoulou A., Lagiou P., Trichopoulos D., Palli D., Pala V., Tumino R., Vineis P., Panico S., Peeters P.H., Dik V.K., Weiderpass E., Lund E., Garcia J.R., Zamora-Ros R., Pérez M.J., Dorronsoro M., Navarro C., Ardanaz E., Manjer J., Almquist M., Johansson I., Palmqvist R., Khaw K.T., Wareham N., Key T.J., Crowe F.L., Fedirko V., Gunter M.J., Riboli E.: Consumption of dairy products and colorectal cancer in the European Prospective Investigation into Cancer and Nutrition (EPIC). PLoS One. 2013, 9, e72715.

[19] Aune D., Lau R., Chan D.S., Vieira R., Greenwood D.C., Kampman E., Norat T.: Dairy products and colorectal cancer risk: a systematic review and meta-analysis of cohort studies. Ann. Oncol. 2012, 23, 37-45.

[20] Peters U., McGlynn K.A., Chatterjee N., Gunter E., Garcia-Closas M., Rothman N., Sinha R.: Vitamin D, calcium, and vitamin D receptor polymorphism in colorectal adenomas. Cancer Epidemiol. Biomarkers Prev. 2001, 10, 1267-1274. 
[21] Ferrari P., Jenab M., Norat T., Moskal A., Slimani N., Olsen A., Tjonneland A., Overvad K., Jansen M.K., Boutron-Ruault M.C., Clavel-Cheapelon F., Morois S., Rohrmann S., Linseisen J., Boeing H., Bergmann M., Kontopoulou D., Trichopoulou A., Kassapa C., Masala G., Krogh V., Vineis P., Panico S., Tumino R., Van Gils C.H., Peeters P., Bueno-de-Mesquita H.B., Ocke M.C., Skeie G., Lund E., Agudo A., Ardanaz E., Lopez D.C., Sanchez M.J., Quiros J.R., Amiano P., Berglund G., Manjer J., Palmgvist R., Van Guelpen B., Allen N., Key T., Bingham S., Mazuir M., Boffetta P., Kaaks T., Riboli E.: Lifetime and baseline alcohol intake and risk of colon and rectal cancers in the European prospective investigation into cancer and nutrition (EPIC). Int. J. Cancer 2007, 121, 2065-2072.

[22] Park J.Y., Mitrou P.N., Dahm C.C., Luben R.N., Wareham N.J., Khaw K.T., Rodwell S.A.: Baseline alcohol consumption, type of alcoholic beverage and risk of colorectal cancer in the European Prospective Investigation into Cancer and Nutrition - Norfolk study. Cancer Epidemiol. 2009, 33, 347-354.

[23] Fedirko V., Tramacere I., Bagnardi V., Rota M., Scotti L., Islami F., Negri E., Straif K., Romieu I., La Vecchia C., Boffetta P., Jenab M.: Alcohol drinking and colorectal cancer risk: an overall and dose-response meta-analysis of published studies. Ann Oncol. 2011, 22, 1958-1972.

[24] Cuomo R., Andreozzi P., Zito F.P.: Alcoholic beverages and carbonated soft drinks: consumption and gastrointestinal cancer risks. Cancer Treat. Res. 2014, 159, 97-120.

[25] World Cancer Research Fund/American Institute for Cancer Research. Food, Nutrition, Physical Activity, and the Prevention of Cancer: a Global Perspective. Washington DC: AICR, 2007.

[26] Sofi F., Cesari F., Abbate R., Gensini G.F., Casini A.: Adherence to Mediterranean diet and health status: metaanalysis. BMJ. 2008, 337, 1344.

[27] Fung T.T., Hu F.B., Wu K., Chiuve S.E., Fuchs C.S., Giovannucci E.: The Mediterranean and Dietary Approaches to Stop Hypertension (DASH) diets and colorectal cancer. Am. J. Clin. Nutr. 2010, 92, 1429-1435.

[28] Akesson A., Andersen L.F., Kristjánsdóttir A.G., Roos E., Trolle E., Voutilainen E., Wirfält E.: Health effects associated with foods characteristic of the Nordic diet: a systematic literature review. Food Nutr. Res. 2013, 57.

[29] Wolin K.Y., Carson K., Colditz G.A.: Obesity and cancer. Oncologist. 2010, 15, 556-565.

[30] Bardou M., Barkun A.N., Martel M.: Republished: obesity and colorectal cancer. Postgrad Med J. 2013, 89(1055), 519-533.

[31] Ma Y., Yang Y., Wang F., Zhang P., Shi C., Zou Y., Qin H.: Obesity and risk of colorectal cancer: a systematic review of prospective studies. PLoS One. 2013, 8, e53916.

[32] De Pergola G., Silvestris F.: Obesity as a major risk factor for cancer. J. Obes. 2013, 2013, 291546.

[33] Perrigue M.M., Kantor E.D., Hastert T.A., Patterson R., Potter J.D., Neuhouser M.L., White E.: Eating frequency and risk of colorectal cancer. Cancer Causes Control. 2013, 24, 2107-2115.

[34] Ben Q., An W., Jiang Y., Zhan X., Du Y., Cai Q.C., Gao J., Li Z.: Body mass index increases risk for colorectal adenomas based on meta-analysis. Gastroenterology. 2012, 142, 762-772.

[35] Harriss D.J., Atkinson G., George K., Cable N.T., Reilly T., Haboubi N., Renehan A.G.: Lifestyle factors and colorectal cancer risk (1): systematic review and meta-analysis of associations with body mass index. Colorectal Dis. 2009, 11, 547-563.

[36] Wasilewska E., Złotkowska D., Pijagin M.E.: The role of intestinal microflora and probiotic bacteria in prophylactic and development of colorectal cancer. Post. Hig. Med. Dosw. 2013, 67, 837-847.

[37] Culpepper B.S.T., Mai V.: Evidence for contributions of gut microbiota to colorectal carcinogenesis. Curr. Nutr. Rep. 2013, 2, 10-18.

[38] Zhu Q., Gao R., Wu W., Qin H.: The role of gut microbiota in the pathogenesis of colorectal cancer. Tumor Biol. 2013, 34, 1285-1300.

[39] Surh Y.J.: Cancer chemoprevention with dietary phytochemicals. Nat. Rev. Cancer. 2003, 3, 768-780.

\author{
Address for correspondence: \\ Katarzyna Neubauer \\ Katedra i Klinika Gastroenterologii i Hepatologii \\ ul. Borowska 213 \\ 50-556 Wrocław \\ Poland \\ E-mail: kasianeu@gmail.com
}

Conflict of Interest: None declared

Received: 29.09.2015

Revised: 10.10.2015

Accepted: 14.10.2015

Praca wpłynęła do Redakcji: 29.09.2015 r.

Po recenzji: 10.10.2015 r.

Zaakceptowano do druku: 14.10.2015 r. 